NBER WORKING PAPER SERIES

\title{
TRADE LIBERALIZATION AND INCOME DISTRIBUTION
}

Donald R. Davis

NBER Working Paper 5693

\section{NATIONAL BUREAU OF ECONOMIC RESEARCH 1050 Massachusetts Avenue \\ Cambridge, MA 02138 \\ August 1996}

I am grateful to Donald Robbins for stimulating conversations, and to Carolyn Evans for excellent research assistance. I am also grateful for the support for this project from the Harvard Institute for International Development. This paper is part of NBER's research program in International Trade and Investment. Any opinions expressed are those of the author and not those of the National Bureau of Economic Research.

(C) 1996 by Donald R. Davis. All rights reserved. Short sections of text, not to exceed two paragraphs, may be quoted without explicit permission provided that full credit, including $\mathbb{C}$ notice, is given to the source. 
NBER Working Paper 5693

August 1996

\title{
TRADE LIBERALIZATION AND INCOME DISTRIBUTION
}

\begin{abstract}
Empirical work relating trade liberalization and income distribution has identified an important anomaly. The Stolper-Samuelson theorem predicts that trade liberalization will shift income toward a country's abundant factor. For developing countries, this suggests liberalization will principally benefit the abundant unskilled labor. Yet extensive empirical studies have identified many cases with a contrary result. This paper develops a simple theoretical explanation for this anomaly. It shows that countries which are labor abundant in a global sense may see wages decline with liberalization if they are capital abundant in a local sense. The current absence of empirical work that would allow us to identify the relevant local abundance implies that virtually all assertions regarding anticipated distributional consequences of trade liberalization are without foundation. There may likewise be important implications for industrialized countries that border developing countries undertaking trade liberalization, particularly in regard to the incentives for migration.
\end{abstract}

Donald R. Davis

Department of Economics

Harvard University

229 Littauer Center

Cambridge, MA 02138

and NBER

email: ddavis@fas.harvard.edu 


\section{Introduction}

Trade liberalization by developing countries has held forth two promises. The first is that it will raise aggregate income. A growing body of research indicates that this promise has been fulfilled. ${ }^{1}$ The second promise is that the internal distributional consequences of liberalization will be benign. The foundation for this promise is the celebrated Stolper-Samuelson theorem. In simple terms, it says that trade liberalization will benefit a country's relatively abundant factor. ${ }^{2}$ And most developing countries, when compared to the global economy, are relatively abundant in unskilled labor. $^{3}$

Yet the empirical evidence for this second promise is at best mixed A ten-country NBER study coordinated by Krueger (1978) and Bhagwati (1978) considered the issue. The latter summarized the results as follows:

The functional distribution of income, while it can be strongly related to foreign trade regimes in theoretical analysis (e.g. the familiar Stolper-Samuelson theorem), does not appear to show anything like a strong and predictable relationship in the Project studies. [p. 198]

Similar results are reported in a nineteen-country World Bank study coordinated by Choksi, Michaely, and Papageorgiu (1991). Having noted theoretical reasons that one might anticipate improvements in the distribution of income, they conclude:

${ }^{1}$ See Sachs and Warner (1995), and Edwards (1993).

${ }^{2}$ Outstanding reviews of the extensive literature inspired by Stolper and Samuelson (1941) appear in various contributions to Deardoff and Stern (1994).

${ }^{3}$ In Section 3 below we consider the case of more than two factors. 
These are all a priori arguments. What does the evidence show? Unfortunately, it is mixed and fragmentary. In some cases . . the income distribution worsened during the course of liberalization. In roughly as many others, . . the reforms improved the income distribution. But in most cases it is hard to be sure. [p. 55]

Results at odds with the Stolper-Samuelson suggestion appear in the important work of Robbins (1996), whose study of seven countries in Latin America and East Asia showed that in almost all cases the relative skilled to unskilled wage rose after trade liberalization. ${ }^{4}$ Given the influence of the Stolper-Samuelson perspective, these results qualify as an important anomaly.

This paper develops a simple theoretical explanation for this empirical anomaly. ${ }^{5}$ It takes as a central premise that the wide divergence in relative factor endowments precludes factor price equalization (FPE) for the world as a whole. Once accepted, this forces a radical revision in the conventional way of interpreting the Stolper-Samuelson result. Relative factor abundance of a country continues to be central to predicting the Stolper-Samuelson consequences of trade liberalization. However the reference set against which one measures relative factor abundance is no longer the global economy. Instead, factor abundance matters only relative to a smaller set of

${ }^{4}$ A more complete summary of the World Bank study appears in Michaely, Papageorgiu, and Choksi (1991). Similar conclusions were reached by Bourguignon and Morrisson (1991). For the impact of the recent Mexican liberalization on relative skilled to unskilled wages, see Feenstra and Hanson (1995), Feliciano (1996), and Cragg and Epelbaum (1996). Johnston (1995) suggests, based on her study of Colombia, that some previous studies may have relied excessively on data for urban areas.

${ }^{5}$ There are alternative theoretical paths one could pursue to obtain apparently antiStolper-Samuelson results. These include considering factor intensity reversals, the Metzler paradox, higher dimensions of factors, and Deardorff's (1986) woeful FIRLESS FIRWOES. See Bhagwati (1959) and Ethier (1984). Feenstra and Hanson (1995) develop a clever approach to explain the distributional impact of outsourcing on Mexico. It relies on capital movements to raise the size of Mexico relative to the US, hence to shift the marginal good to be more skill intensive. This shifts the structure of relative demand for skill upward in both countries. It does not consider the issue of which competitive margins are relevant, as in the present paper. The attraction of the account developed here is its simplicity and the relevance of its key assumption. 
countries with similar endowment proportions. ${ }^{6}$ A country can be very labor abundant when considered within the context of the global economy. However, if it is capital abundant relative to the countries within its reference set, the distributional consequences will be precisely opposite to those one would anticipate with a more conventional interpretation of Stolper-Samuelson.

Nor are the consequences of these observations limited to the developing world. Recent discussions of trade liberalization agreements between industrialized and developing countries, as in NAFTA, have focused on their potential impact on migration. In the simplest form, this has involved the following logic: If wages for the unskilled rise in the developing country, then migration will decline; trade liberalization will raise wages for the unskilled; therefore trade liberalization will help to stem migration. The model developed in this paper makes clear that the premise that liberalization will raise wages for the unskilled in the developing country is open to question, and so correspondingly is the conclusion that migration will decline. ${ }^{7}$

${ }^{6}$ As will be developed below, the relevant reference set is composed of those countries within the same "cone of diversification." They have similar endowment proportions and produce the same range of goods. Under free trade, and with identical constant returns to scale technologies, there will be FPE among members of the same cone, but not between cones. See Dixit and Norman (1980). This type of model was key to the theoretical approach of Krueger (1977). It has also been used by Bhagwati (1984), who made it the centerpiece of his explanation for the Kravis, Heston, and Summers (1982) observation that services are cheaper in poor countries. Leamer (1987) uses such a model to identify differing "paths of development." Leamer and Levinsohn (1995) have urged empirical researchers to investigate the multi-cone model more closely, especially when (as in the present case) the problem of interest concerns both developing and developed countries.

${ }^{7}$ Indeed the available empirical work on Mexico's liberalization suggests that the unskilled wage has fallen sharply relative to skilled wages, even prior to the foreign exchange crisis. See Feliciano (1996). The lessons of the present paper are relevant to this experience, since the sharpest change in Mexico's trade policy was its autonomous liberalization prior to the NAFTA agreement. 


\section{The Model}

Consider a Heckscher-Ohlin world with many countries, three goods, and two factors. Both goods and factor markets are perfectly competitive. Technologies are constant returns to scale. For simplicity, assume they employ fixed coefficients. The two factors of production are capital and labor, and are available within each country in fixed supply. ${ }^{8}$ The three goods are $\mathrm{X}, \mathrm{Y}$ and $\mathrm{Z}$, in decreasing order of capital intensity, as reflected by $\mathrm{k}_{\mathrm{X}}>\mathrm{k}_{\mathrm{Y}}>\mathrm{k}_{\mathrm{Z}}$. Each country is small relative to the world economy, so may treat international goods prices as fixed independently of its trade policy choices.

An important assumption is that cross-country endowment differences are too strong for the world trading system to replicate the equilibrium of a fully integrated world economy in the sense of Dixit and Norman (1980). Accordingly, factor prices are not equalized for the world as a whole. The capital abundant countries will have the higher wage to rental ratio, $\omega^{\mathrm{N}}>\omega^{\mathrm{S}}$. This framework is depicted in the well-known Lerner diagram in Figure 1.

${ }^{8}$ Recent discussions have focused on redistribution between skilled and unskilled labor. One can simply substitute "skill" for "capital" to make this relevant for these discussions. Alternatively, if capital is internationally mobile with an interest rate determined in the larger world economy, it would be straightforward to describe a three-factor model in which observations of the skilled to unskilled wage corresponded very strongly with the results described here for a two factor model. See the discussion in Wood (1994). 


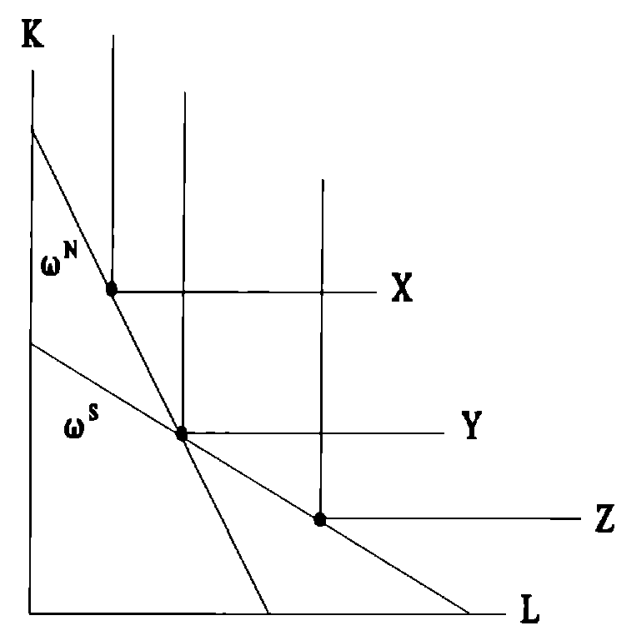

Figure 1 Heckscher-Ohlin Without FPE

We assume that for all countries $c$, the endowment ratio $k^{c} \in\left(k_{\mathrm{Z}}, k_{\mathrm{X}}\right)$, and $k^{c} \neq k_{\mathrm{Y}}$, so that all countries have diversified production. We will refer to the set of countries for which $\mathrm{k}^{\mathrm{c}} \in\left(\mathrm{k}_{\mathrm{Y}}\right.$, $\left.k_{\mathrm{X}}\right)$ as the North, and that for which $k^{c} \in\left(k_{\mathrm{Z}}, k_{\mathrm{Y}}\right)$ as the South. These endowment differences lead countries of the North to produce only the goods $\mathrm{X}$ and $\mathrm{Y}$, and countries of the South to produce goods $\mathrm{Y}$ and $\mathrm{Z} .{ }^{9}$ That is, the world has two cones of diversification. The endowments of a particular country may be represented as a point within the cone that defines its region [see Figure 2].

${ }^{9}$ Wood (1994) and Leamer (1996) raised the issue of "non-competing" goods in their discussion of the rising skill premium in the United States and United Kingdom. Here $X$ is a noncompeting good for the North, as is $Z$ for the South. $Y$ is a competing good for each. The fact that there is a good produced in common is not essential for the results here. The emphasis in each of the papers noted above to the importance of non-competing goods is consistent with the type of multi-cone, no-FPE model developed here. 


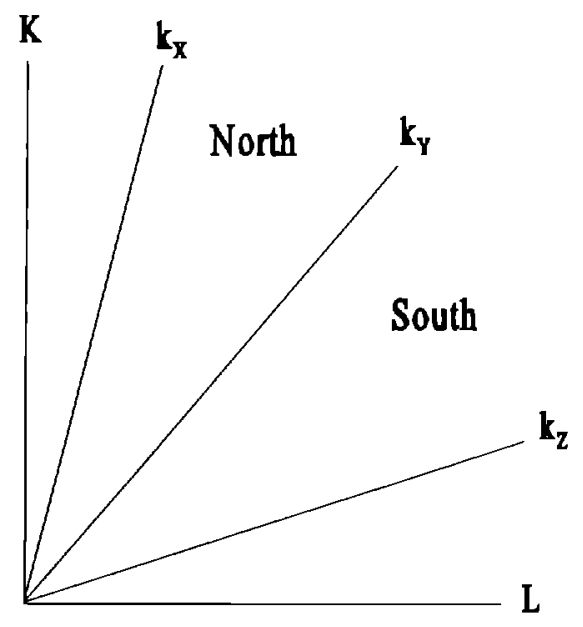

Figure 2 Diversification Cones

At this point we must consider a distinction that will prove crucial to our analysis of the distributional effects of trade liberalization. Each North country is more capital abundant than any South country. Thus we may sensibly call the North countries the capital abundant countries, and the South the labor abundant countries, in a global sense. However, it turns out that this global sense of factor abundance is not relevant for predicting the Stolper-Samuelson effects of trade liberalization. Instead, what is crucial is the local factor abundance, i.e. within the country's cone of diversification. We will make this more precise by considering the case of the South.

All countries of the South produce the same set of goods, $Y$ and $Z$. However their trade patterns vary depending on their relative factor abundance within the cone. These break down into three cases, depicted in Figure $3 .{ }^{10}$ All countries of the South must import $\mathrm{X}$, since it is not produced there. The most capital abundant of the South countries are those in region A. They

${ }^{10}$ This tripartite division invites the appellation "Neapolitan" cones. In higher dimensions of factors, as seen below, this feature is preserved in cross section. 
produce a great deal of $Y$ and very little $Z$. Accordingly, exports of $Y$ are used to finance not only imports of $X$, but also of $Z$. The least capital abundant countries are those in region $A^{\prime}$, a designation chosen to emphasize that the export patterns of $A$ and $A^{\prime}$ are complementary. ${ }^{11}$ Those in $\mathrm{A}^{\prime}$ produce a great deal of $Z$, but very little $\mathrm{Y}$. Accordingly, exports of $Z$ are used to finance not only imports of $\mathrm{X}$, but also of $\mathrm{Y}$. Those at an intermediate level of capital abundance, in region $\mathrm{M}$, satisfy their own needs for both $\mathrm{Y}$ and $\mathrm{Z}$, and so export both in exchange for $\mathrm{X}$.

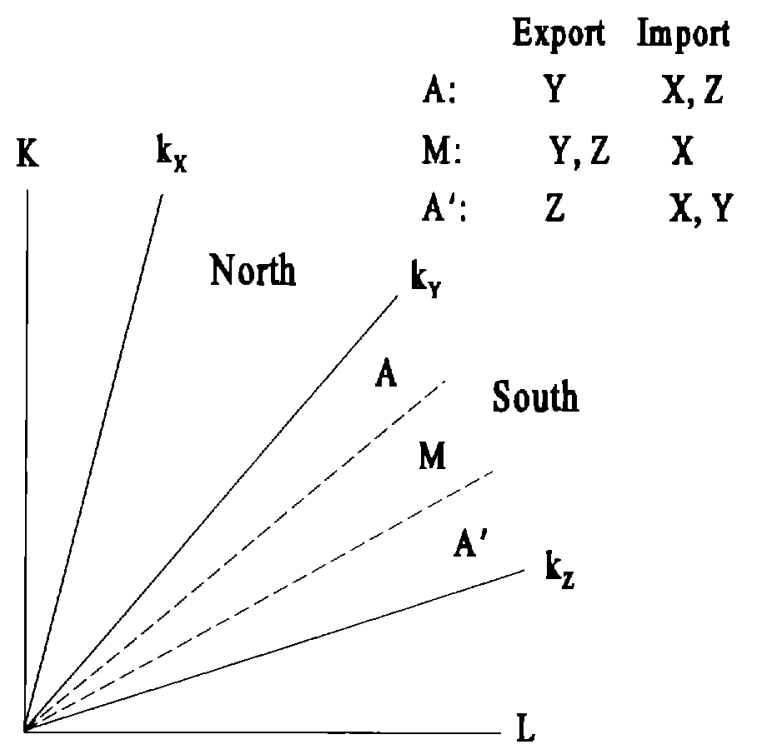

Figure 3 Varied Trade Patterns of the South

We consider now the effects of trade liberalization for three countries representative of the three regions of the South identified in Figure 3. Assume that each initially has in place a uniform

${ }^{11}$ Whenever we speak of two countries as having complementary export patterns, we always mean relative to the set of goods produced within the cone. Such pairs of countries with complementary trade patterns will figure prominently in our discussion in Section 3 below of the case of more than two factors. 
ad valorem tariff at rate $\tau$ on all imports. ${ }^{12}$ Consider first the case of a representative country $\alpha$ from South region $\mathrm{A}$. The determination of factor returns can be examined in a diagram taken from Mussa (1979), and appears as Figure 4.

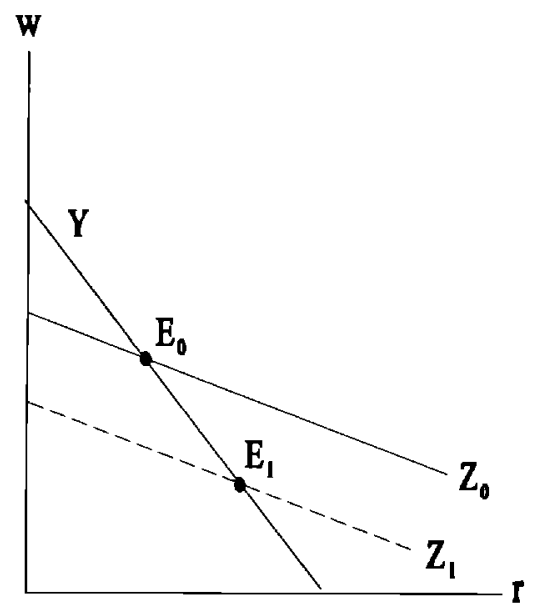

Figure 4 Trade Liberalization in a Locally

Capital Abundant Country of the South

In the case of Leontief technologies, the zero profit frontiers are linear in factor price space. An important insight for our results comes from the fact that Figure 4 does not feature the zero profit frontier for the good X. We could place it in this space, but since country $\alpha$ (as all countries of the South) does not produce $\mathrm{X}$, the corresponding zero profit frontier plays no role in the determination of factor prices. As a result, the elimination of protection on $\mathrm{X}$ which lowers the domestic price of $X$ in country $\alpha$ likewise has no influence on local factor prices. However, the fact that protection is eliminated on $\mathrm{Z}$, lowering its domestic price, leads the corresponding zero

${ }^{12}$ We assume that the country's tariff is at a level that leaves the qualitative pattern of exports and imports unchanged from that under a regime of free trade. 
profit frontier to shift in. The exportable $\mathrm{Y}$ remains at the fixed world price, so experiences no shift in the zero profit frontier. The equilibrium of country $\alpha$ shifts from $E_{0}$ to $E_{1}$ in Figure 4 .

Trade liberalization in country $\alpha$ has lowered wages and raised rentals. This occurs in spite of the fact that it is capital poor and labor rich in the global sense (since it is a member of the South). The crucial element is that it is capital abundant in the local sense, i.e. within its own cone. It is also important to realize that not a word has been said about the volume of trade between country $\alpha$ and its various trading partners. The reason is that the volume of trade plays no role in the determination of factor prices, hence the purely distributional consequences of liberalization. ${ }^{13}$ Thus our results here would not be affected even if a large majority of the trade of this country is with the North. ${ }^{14}$

It is straightforward to replicate this experiment for countries of the South in regions $M$ and $\mathrm{A}^{\prime}$. In the case of a country from region $\mathrm{A}^{\prime}$, we will get the more conventional result that trade liberalization will raise wages and lower rentals. Yet this occurs for an unconventional reason. Trade liberalization raises wages for a country in region $\mathrm{A}^{\prime}$ because it is labor abundant within the cone of the South, not because of its labor abundance relative to the North. Finally, in

${ }^{13}$ As pointed out by Bhagwati (1959), an analysis of distributional effects should also take into account the manner in which government tariff revenues are distributed. We abstract from this by assuming that government revenues are distributed to factors in proportion to their share of market income. In this case, and with endowments fixed, the wage to rental ratio is sufficient to describe the distributional shares.

${ }^{14}$ Of course, changes in trade volumes will matter a great deal for the overall welfare consequences of the liberalization. For small movements in the tariff, these effects are given by the classic formula $d V=-m d p^{*}+t d m$. The first term is zero because of the small country assumption, leaving only aggregate gains from the rise in trade volume with liberalization. 
region $\mathrm{M}$, income distribution is entirely unaffected by the removal of protection, since the zero profit frontiers for the two exportables do not shift.

Using these results, we can depict the impact of trade liberalization on the wage to rental ratio for the various regions within both the North and the South. This appears as Figure 5.

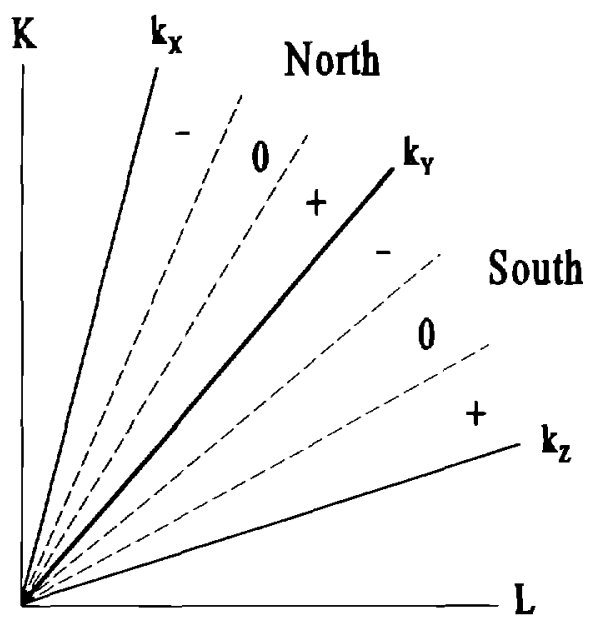

Figure 5 Impact of Trade Liberalization on the Wage to Rental Ratio

An interesting comparison emerges with respect to the most labor abundant countries of the North and the most capital abundant countries of the South. They share a common trade pattern, exporting $\mathrm{Y}$ for imports of $\mathrm{X}$ and $\mathrm{Z}$. Nevertheless autonomous trade liberalization has exactly opposite consequences for the two. Yet more curiously, it raises wages for the country of the North, and depresses them in the South, in spite of the fact that the North countries we are examining are more capital abundant than the South countries. The reason, again, is that this direct (global) comparison of factor abundance is irrelevant for the Stolper-Samuelson effects of trade liberalization. What is crucial is the local factor abundance, relative to one's own cone, and correspondingly the product mix relevant in determining local factor prices. 


\section{Generalizations}

Thus far we have worked with a highly simplified two-factor model. Yet empirical research often invites an extension of the list of factors to include land and other resources, as well as to distinguish between qualities of labor. Thus it is important to know how our results generalize when we include more factors of production. ${ }^{15}$

There are two principal results whose robustness we would like to confirm. One is that a country's factor abundance relative to the global economy is irrelevant for predicting the distributional consequences of liberalization -- instead one needs to know the abundance within that country's production cone. This is a subtle problem, since with more than two factors we no longer have a scalar ordering of relative abundance.$^{16}$ Nonetheless, the essential point from the two factor case is robust. All and only those countries strictly within a specific cone share a common set of zero profit conditions under free trade. And the pattern of exports and imports of these goods, hence the relative price movements to be expected under liberalization, depends on

${ }^{15}$ It is well known that when one moves to higher dimensions the one-to-one mapping between the price of a specific good and the qualitative impact on a particular factor is preserved only under special conditions [see the excellent discussion in Ethier (1984)]. However, as evidenced by the brilliant paper of Leamer (1987), it is possible to move beyond the two factor setting and relate these links between goods prices and factor returns to interesting features of economic structure. Leamer's paper likewise illustrates that adding more factors poses no problem for the existence of the cones of diversification which are the premise of the present study

${ }^{16}$ It would be straightforward in Leamer's (1987) three factor framework to provide an example in which one country had both more capital and more land per worker than a country in another cone, but in which trade liberalization raises wages in the former and lowers them in the latter. The key, of course, would be their endowments -- so export pattern -- within their respective cones. This corresponds to the comparison of the locally labor abundant North country with the locally capital abundant South country in Section 2 above. 
the composition of a country's endowments within the cone. Moreover, since as we show below, members of a single cone can have precisely opposite distributional consequences of liberalization, it is clearly impossible for any ordering across different cones to provide interesting contrasts regarding qualitative changes in factor returns.

The second result whose robustness we want to check concerns the structure of the distributional consequences of liberalization within a cone. In the two factor case, there is a region of endowments in which all locally produced goods are exported, so that trade liberalization has no distributional consequences. In addition, there is a pair of regions with complementary trade patterns, for whom the distributional consequences of liberalization are precisely reversed.

When we move to cases with more factors, the essential structure is very similar. There remains a single region in which liberalization has no distributional consequences. The one significant change is that now there is more than one set of paired regions. ${ }^{17}$ One observation serves as the foundation for this assertion. Within the cone, and under balanced trade, there exist regions of endowments that support every combination of exports of the goods that define the cone. This always includes the case in which all locally produced goods are exported. Beyond this, the regions break down into pairs, with export patterns that are complementary relative to the set of locally produced goods. Since our experiment concerns small countries reducing a uniform ad valorem tariff, there will be no relative price changes within export- and importcompeting goods respectively, so each can be aggregated. It is clear then that trade liberalization by countries in paired regions is affecting only a single relative price of locally produced goods.

\footnotetext{
${ }^{17}$ For example, in the three factor world there will be three sets of paired regions in a cone, as well as a single region in which all goods are exported.
} 
And because their export patterns are complementary, liberalization moves this price in opposite directions. Thus, whatever the distributional consequences of trade liberalization of a country in one region, we know that for a country in the paired region they will be precisely reversed.

\section{Conclusion}

This paper has developed a simple model to consider the impact of trade liberalization on income distribution. Its one departure from conventional theory is to assume that relative endowment differences in the world are too large to allow for factor price equalization. And it has demonstrated that once this premise is allowed, it is necessary to make a radical revision in the conventional view of the impact of trade liberalization on income distribution.

It is conventional to argue that if a country is labor abundant relative to the global economy, then trade liberalization will redistribute income toward labor. However in our framework, such a conclusion is without foundation. The relevant factor abundance comparison is not to the global economy, but relative to the cone within which one produces. Thus a country that is very labor abundant relative to the global economy, but capital abundant relative to its own cone, will find that trade liberalization reduces wages. Parallel results emerge in a model with a larger number of productive factors.

As Leamer and Levinsohn (1995) point out, there is currently no empirical work identifying international production cones. In our framework, it follows that virtually all assertions with respect to the anticipated distributional consequences of trade liberalization are without foundation. We hope that this theoretical result will stimulate empirical work to identify these cones, and so to identify the expected distributional effects of trade liberalization. 


\section{References}

Bhagwati, J. (1984) "Why are Services Cheaper in the Poor Countries," Economic Journal 94: 279-286.

Bhagwati, J. (1978) Anatomy and Consequences of Exchange Control Regimes, Cambridge: Ballinger.

Bhagwati, J. (1959). "Protection, Real Wages and Real Incomes" Economic Journal, 69, 733748.

Bourguignon, F. and C. Morrisson (1991) External Trade and Income Distribution, Paris: OECD.

Choksi, A., M. Michaely, and D. Papageorgiu (1991) "The Design of Successful Trade Liberalization Policies," in A. Koves and P. Marer, eds., Foreign Economic Liberalization, Boulder, CO: Westview Pr.

Cragg, M. and M. Epelbaum (1996) "The Premium for Skills in LDCs: Evidence From Mexico," mimeo, Columbia University and Centro de Investigacion Economica, ITAM.

Deardorff, A. (1986) "FIRLESS FIRWOES: How Preferences can Interfere with the Theorems of International Trade," Journal of International Economics, 20, 131-142.

Deardorff, A. and Stern, R., eds. (1994) The Stolper-Samuelson Theorem: A Golden Jubilee, Ann Arbor: U. Of Michigan.

Dixit, Avinash K. and Norman, Victor F. (1980) Theory of International Trade, Cambridge: Cambridge University Press.

Edwards, S. (1993) “Openness, Trade Liberalization, and Growth in Developing Countries," Journal of Economic Literature, 31:3, 1358-93.

Ethier, W. (1984) "Higher Dimensional Issues in Trade Theory," in R. Jones and P. Kenen, eds. The Handbook of International Economics, vol. 1, New York: Elsevier.

Feenstra, R. and Hanson, G. (1995) "Foreign Investment, Outsourcing and Relative Wages," forthcoming in Political Economy of Trade Policy: Essays in Honor of Jagdish Bhagwati, Cambridge: MIT Pr.

Feliciano, Z. (1996) "Workers and Trade Liberalization: The Impact of Trade Reforms in Mexico on Wages and Employment," mimeo, Queens College.

Johnston, L. (1995) "Trade Liberalization and Income Distribution" mimeo, Harvard University.

Kravis, I., A. Heston, and R. Summers (1982) "The Share of Services in Economic Growth," in F.G. Adams and Bert Hickman, Global Econometrics: Essays in Honor of Lawrence R. Klein, Cambridge: MIT Pr.

Krueger, A. (1978) Liberalization Attempts and Consequences, Cambridge: Ballinger.

Krueger, A. (1977) Growth, Distortions and Patterns of Trade Among Many Countries, Princeton Studies in International Finance, No. 40, February.

Leamer, Edward (1996) "In Search of Stolper-Samuelson Effects Between Trade and US Wages" mimeo, Yale and UCLA.

Leamer, E. (1987) "Paths of Development in the Three-Factor, n-Good General Equilibrium Model," in Journal of Political Economy, 95:5, 961-99.

Leamer, E. and Levinsohn, J. (1995) "International Trade Theory: The Evidence," in G. Grossman and K. Rogoff, eds. The Handbook of International Economics, vol. 3, New York: Elsevier. 
Michaely, M., D. Papageorgiu, and A. Choksi (1991) Liberalizing Foreign Trade: Lessons of Experience in the Developing World, vol. 7, Cambridge, MA: Basil Blackwell.

Mussa, Michael A. (1979) "The Two-Sector Model in Terms of its Dual: A Geometric Exposition," Journal of International Economics, 9, No. 4, 513-526.

Robbins, Donald (1996) "Trade, Trade Liberalization and Inequality in Latin America and East Asia -- Synthesis of Seven Country Studies," mimeo, Harvard Institute for International Development, March.

Sachs, J. and A. Warner (1995) "Economic Reform and the Process of Global Integration," mimeo, Harvard University.

Stolper, W. and P. Samuelson (1941) "Protection and Real Wages," Review of Economic Studies, November, IX, 58-73.

Trefler, D. (1993) “International Factor Price Differences: Leontief was Right!" Journal of Political Economy, 101.

Wood, A. (1994) North-South Trade, Employment and Inequality: Changing Fortunes in a SkillDriven World, New York: Oxford. 